\title{
Standards of Competency of Head of School Beginners as Leaders in Learning Innovation
}

\author{
Ibrahim Bafadal \\ Department of Educational Administration \\ Universitas Negeri Malang, Indonesia \\ ibrahim.bafadal.fip@um.ac.id
}

\author{
Ahmad Yusuf Sobri \\ Department of Educational Administration \\ Universitas Negeri Malang, Indonesia \\ ahmad.yusuf.fip@um.ac.id
}

\author{
Ahmad Nurabadi \\ Department of Educational Administration \\ Universitas Negeri Malang, Indonesia \\ ahmad.nurabadi.fip@um.ac.id \\ Imam Gunawan \\ Department of Educational Administration \\ Universitas Negeri Malang, Indonesia \\ imam.gunawan.fip@um.ac.id
}

\begin{abstract}
This study aims to describe the personal, social, and professional competencies that a novice must possess in order to effectively begin his performance as an innovative learning leader. This research was conducted with a quantitative. The targets of this study were 10 principals in metropolitan cities, central cities and suburbs for elementary schools in East Java. The data of this study were collected by a closed questionnaire and in-depth interviews. Quantitative data collected was analysed by quantitative data analysis techniques using descriptive statistics of middle size trends. Based on data analysis, the results of the study can be concluded as follows, novice principals need competencies related to openness, responsibility, honesty, talent and work interest, integrity, and self-confidence. Social competencies needed by beginner school principals are competencies related to social sensitivity, providing assistance to others, communicating, cooperating, and participating in social activities. Beginner school principals most need competence regarding vision of learning, then proceed with a culture of learning, learning environment, and school community relations.
\end{abstract}

Keywords: beginner principal, leader, learning innovation, competency standard

\section{INTRODUCTION}

The principal as a critical factor in the success of improving school quality and overall school success has also been cited by Lunenburg (2010). Many field studies conclude that effective leadership from a school principal has a positive relationship and is very significant or has a strong influence on student achievement. Even more than just student achievement. various studies show that effective school leadership has a strong influence on student attendance, student engagement with school, student academic self-efficacy, staff satisfaction, and collective teacher efficacy. There is a significant positive correlation between the effectiveness of school-based management and the leadership performance of school principals (Bafadal, Wiyono, \& Sobri, 2015).

The principal's position as a learning leader is very important, especially in making learning innovations. However, while on the other hand, the performance of existing principals has not been more focused on learning leadership. Some indicators that appear so far. First, there are so many schools that do not have a clear and correct vision, mission, goals and target school (shared vision). Even if it is clear and true, the formulation of the school's vision, mission, goals, and targets is not socialized and internalized to the school community and community, especially parents of students. Even when the school principal was asked about the formulation of the vision, mission, goals, and targets of his school, it turns out the school itself cannot explain it, aka forget.

Moreover, teachers are increasingly unable to explain the vision, mission, goals, and targets of their schools, because they have never been included in the formulation or improvement of the vision, mission, goals and targets of the school, and have not received socialization of the vision, mission, goals and targets of the school by the principal. It cannot be denied that the formulation of the school's vision, mission, goals, and targets is displayed or displayed on the sides of the school wall, but only in fulfilling the formal obligations of the school and has not become a process of internalizing the vision, mission, goals and targets of the school for all citizens school.

Second, the principal has not given much attention to efforts to create a learning culture. It is hard to believe, that in schools, especially schools of "plate merat" aka public schools that have standard operational procedures (SOP) in a cluster of substance and learning curriculum, for example: SOP Compilation of Lesson Plan, SOP Implementation of Learning, SOP Learning Evaluation Implementation, SOP of Remedy Learning Program, SOP of Enrichment Learning Program, SOP of Extracurricular Lesson Plan Preparation Development, SOP of Extracurricular Learning Implementation, SOP of Extracurricular Learning Evaluation Implementation, SOP of Development of Character Building, and SOP of Culture Development.

Third, the principal gives less attention to his leadership in creating an effective learning environment for learning and student growth (learning environment). For example, there are so many primary schools that are very limited in having media and learning tools so it is not possible for an effective learning process to run in the school, while existing school funds are used to not meet the shortcomings or needs of the media and learning tools that can support an effective learning process, but is used to take part in School Health Business Competitions, buy 
various plants and school green paints to achieve the ambitions of the Mayor, the Head of the Education Office, and the Principal to win the Adiwiyata School award (Bafadal, 2015).

Regarding the competency standard of school principals in Indonesia has been regulated through the Minister of National Education Regulation Number 13 of 2007 concerning Principal / Madrasah Standards. The regulation emphasizes that there are five competency standards for principals / madrasas. First, personality competencies, including: (1) having the integrity of personality as a leader; (2) have a strong desire in selfdevelopment as a school principal; (3) being open in carrying out basic tasks and functions; (4) have the ability to control themselves when facing problems at work as a school principal; and (5) having an interest in the position of educational leader. Second, managerial competencies, including: (1) being able to lead schools in the context of optimally utilizing school / madrasah resources through transformational leadership; (2) able to manage school changes / development towards schools as effective learning organizations; (3) able to create a conducive and innovative culture and school / madrasah climate for students' learning; and (4) able to manage teachers and staff in the context of optimizing the use of school human resources.

Third, entrepreneurial competencies, including: (1) able to create innovations that are useful for school development; (2) working hard to achieve school success as an effective learning organization; (3) have strong motivation to succeed in carrying out their main tasks and functions as school managers; (4) never give up and always look for the best solution in facing obstacles faced by schools; and (5) have an entrepreneurial instinct in managing school / madrasah production / service activities as a source of student learning. Fourth, supervision potential, including: (1) being able to plan academic supervision programs in order to increase teacher professionalism; and (3) being able to carry out academic supervision of teachers using appropriate approaches and supervision techniques; and (3) able to follow up on the results of academic supervision of teachers in order to improve teacher professionalism. Fifth, social competence, including: (1) being able to work with other parties for the benefit of the school; and (2) have social sensitivity towards other people or groups.

Furthermore, according to Hoy and Miskel (1987), the development of principals 'competency standards is the beginning of all principals' professionalism improvement programs. Competency standards are the basis for recruiting prospective principals, principals' certification, principals' education and training, and evaluating principals' performance. In the same way Frymier and his friends (1984) and Sergiovanni (1987) detailed various types of school professionalism improvement programs, namely: (1) the use of a strict licensing system in each recruitment of prospective principals, the position of the principal may be held only by teachers who have teachers certificate to be a school principal; (2) the headmaster's performance evaluation by the principal himself (self-evaluation); (2) external performance of school principals (external reviewers); (3) continuous supervision by the authorities; programmable, continuous and comprehensive professional training (In-service training); (5) welfare development; (6) the provision of preservation of the principal in accordance with the performance of the principal; and (7) the provision of facilitation for protection facilities when the school principal experiences social, legal, economic conflicts with the community.

\section{METHOD}

This study uses a quantitative approach. Data collection and analysis with a quantitative approach (Creswell and Clark, 2007). Based on the formulation of the research problem, the data collected and analysed are personal, social, and professional competencies that must be possessed by novice principals so that they can effectively begin their performance as learning leaders. First of all, the data is collected and analysed through a quantitative approach, so that by its nature, this research is a descriptive study. Descriptive means that this research seeks to obtain information regarding phenomena that are observed today and does not intend to test hypotheses (Kerlinger, 1986; Borg and Gall, 1992).

\section{RESULT}

Description Personal Competencies that Must be Possessed by Novice School Principals to Effectively Develop Their Personality as Learning Leaders

Based on the data obtained, it can be seen from 41 respondents, the number of respondents in very good qualifications was 30 respondents or $73.17 \%$, in qualifications both 11 respondents or $26.83 \%$, in qualifications as much as 0 respondents or $0 \%$, and there are no respondents on low qualifications. So, it can be concluded that the personal competencies that must be possessed by beginner school principals in the category of very good or very high. There are 6 factors in personal competency that a beginner school principal must possess. Factors that must be possessed by beginner principals have different values according to the situations and conditions faced by novice principals in developing their personality as learning leaders. It is known that the openness and responsibility factors both have the highest percentage or average value of 88.01 and an average value of 3.52. Thus it can be concluded that in the personal competency that must be possessed by the novice headmaster so that he can effectively develop his personality as a learning leader, the openness and responsibility factors are most needed, then successively followed by factors of honesty, talents and interests in office, integrity, and which The last factor is self-confidence.

\section{Description of Professional Competence that a Beginner School Principal Must Possess in Order to Effectively Deliver Herself as a Learning Leader}

Based on the data obtained, it can be seen from 41 respondents, the number of respondents who are in very good qualifications as many as 16 respondents or $39.02 \%$, in qualifications as good as 25 respondents or $60.98 \%$, in qualifications as much as 0 respondents or $0 \%$, and there are no respondents on low qualifications. So, it can be concluded that the professional competencies that must be possessed by beginner school principals in order to effectively be able to deliver themselves as learning leaders 
in good or high categories. There are 4 factors in the professional competency that beginner principals must have. Factors that must be possessed by the Beginner School Head have different values according to the situation and conditions faced by the novice headmaster in delivering himself as a learning leader. It is known that the vision of learning factor has the highest percentage or average value of 84.09 and the average value is 3.36. Thus, it can be concluded that in the professional competencies needed by the novice headmaster, novice principals need the most competence about vision of learning, then successively proceed with the factors of culture of learning, learning environment, and school-community relations.

Description of Social Competence that a Beginner School Principal Must have in Order to Effectively be Able to Begin his Performance as a Learning Leader

Based on data obtained during the study, it can be seen from 41 respondents, the number of respondents in the qualifications is very good as many as 19 respondents or $46.34 \%$, in qualifications as many as 22 respondents or $53.66 \%$, in qualifications as much as 0 respondents or $0 \%$, and there are no respondents on low qualifications. So, it can be concluded that the social competencies that beginner principals must have in order to effectively be able to start their performance as learning leaders in the good or high category. There are 5 factors that must be possessed by the Beginner School Principal. Factors faced by Beginner Principals have different values according to the conditions faced by beginner novice principals so that they can effectively begin their performance as learning leaders. It is known that the social sensitivity factor has the highest percentage or average value of 84.02 and an average value of 3.36. Thus, it can be concluded that in the social competencies needed by novice principals most need social competence factors about social sensitivity, then successively followed by factors providing assistance to other parties, communication, working together, and participating in social activities.

\section{DISCUSSION}

When we talk about personality, that we are talking about is not only someone who has charm, a positive attitude towards life, a smiling face, or a finalist in this year's Miss America contest. Psychologists view personality / personality as a dynamic concept that describes the growth and development of a person's entire psychological system (Robbins, 2003).

The most commonly used definition of personality was put forward by Gordon Allport almost 70 years ago. He said that personality is a dynamic organization in each psychophysical system that determines unique adaptations to the environment. Human behavior is influenced by many factors, both from inside and outside. As a person, humans need to develop themselves, so that in the future he can appear as a steady and harmonious human being. In developing themselves, humans must use feelings, culture, personal will and develop harmonious relationships with the environment (Soedarsono, 1999).

In carrying out managerial tasks, principals are required to have personal / personal competencies, these competencies require principals to have: (1) strong personal / personal integrity, which in this case is marked by consistent thinking, commitment, assertiveness, discipline in carrying out tasks; ( 2 ) have a strong desire to develop themselves as school principals, in this case includes having a high sense of curiosity about policies, theories, new practices, able to independently develop themselves as efforts to fulfil curiosity; (3) being open in carrying out tasks, includes the tendency to always want to inform transparently and proportionately to others about the plan, the process of implementation and the effectiveness of the program; (4) able to control themselves in facing problems at work; and (5) have the talent and interest in the position as a leader. Muchith (2007) explains that personality / personal competence as a set of personal abilities and characteristics that reflect the reality of attitudes and behavior in carrying out their daily tasks. A simpler understanding is conveyed from personality competence, which is the ability to be an example. This exemplary according to Sarimaya (2008) is a personal ability that reflects a personality / personality that is steady, stable, mature, wise, and authoritative, so that it becomes and has a noble character.

Personality / personal competence must at least contain knowledge of social and religious customs, knowledge of culture and tradition, knowledge of the core of democracy, knowledge of aesthetics, appreciation and social awareness, correct attitude towards knowledge and work and loyalty to human dignity and dignity. Personal development independently can be carried out with the following efforts: (1) trying to understand fundamentally and comprehensively that personal / personal development that is steady, stable, mature, wise, and authoritative, be an example for others and having good character will be one of the pillars quality education; (2) develop empathic personality / personal aspects in daily life, which include the following aspects: first, respect and appreciation for oneself, meaning that they must have a strong sense of selfworth that is capable of relating to others on the basis of positive things, secondly, good will, which includes sincere, honest interest in the happiness of others, respect, trust and respect for others, and avoid using others to meet personal needs.

Third, develop yourself into an autonomous person through the development of life in accordance with his personality / person while open to learning from others, and internalize various concepts with existing conditions, fourth, trying to be an example, by always controlling and controlling his awareness that what is given to others, what is said and done is not only accepted but will also be imitated, fifth, oriented to grow and develop, in the sense of trying to be open in order to expand the horizons of his being, and try to improve the quality of his personality / person.

Sugiharto (2008) states that to develop a person, among others, can be done by: (1) developing effective living habits, in this case acting and acting proactively, which means more than just taking the initiative. Being proactive means being responsible for our own behavior (past, present and future) and making choices based on principles and values rather than on mood or circumstances. Proactive people are agents of change and choose not to be victims, not to be reactive, not to blame others. They do this by developing and using an inside out approach to create change. 
They are determined to be a creative driving force in their own lives, which is the most fundamental decision; (2) referring to the final goal, everything is created twice first mentally, second physically. Individuals, families, teams and organizations shape their future by first creating a vision and goals. They are not living their lives day after day without a clear purpose in their minds. Mentally they identify the principles, values, relationships, and goals that are most important to themselves and make a commitment to themselves to carry them out. A mission statement is the highest form of commitment to oneself to carry it out. The mission statement is the main decision, because it underlies other decisions. Creating a culture of common mission, vision and values is at the core of leadership; (3) prioritizing the main, namely the second creation physically. Putting first the priority means organizing and implementing, what has been created mentally. Secondary matters do not take precedence. The main things are not neglected, individuals and organizations focus their attention on what is most important, whether urgent or not. The point is to make sure the priority is first; (4) winning thinking, which is a way of thinking that seeks to achieve mutual benefit and is based on mutual respect in all interactions. In family and work life, the members think interdependently with the term "we", not me. Win / win thinking encourages conflict resolution and helps each individual to find mutually beneficial solutions; and (5) creating synergy, which is to produce a third alternative, not my way, not yours, but a third way that is better than ours each. Take advantage of differences in solving problems, taking advantage of opportunities. Synergistic teams and families utilize the strengths of each individual as a whole to put aside mutual harm. Working to improve personal quality is very important, this personal quality improvement from the level of reactive personality, proactive personality, independent personality, towards spiritual personality (Nugroho, 2008).

There are 6 factors in personal competency that a beginner school principal must possess. Factors that must be possessed by beginner principals have different values according to the situation and conditions faced by beginner principals in developing their personality / personality as learning leaders. From the results of the study it can be seen that the factors of openness and responsibility have the same percentage or average value. highest average. Thus it can be concluded that in the personal competency that must be possessed by novice principals so that they can effectively develop their personality / personalities as learning leaders most openness and responsibility factors are needed, then successively followed by factors of honesty, talent and interest in office, integrity, and finally the confidence factor.

The principal is one of the education components that has the most role in improving the quality of education. For this reason, the principal must know the tasks that must be carried out. The tasks of the principal as stated Wahjosumidjo (2007) that the principal works with and through other people. The principal acts as a communication channel in the school environment, including: (1) the principal is responsible and accountable. The head of the school acts and is responsible for all actions carried out by subordinates; actions made by teachers, students, staff, and parents of students cannot be separated from the responsibility of the principal; (2) with limited time and resources, a school principal must be able to face various problems; with all the limitations, a school principal must be able to arrange assignments quickly and can prioritize if there is a conflict between the interests of subordinates and the interests of the school; (3) the principal must think analytically and conceptually; the principal must be able to solve the problem through an analysis, then solve the problem with a feasible solution, and must be able to see each task as a related whole; (4) the principal is a mediator or mediator; in the school environment as an organization, it consists of people who have different backgrounds that can cause conflict; therefore, the principal must be an intermediary in the conflict; (5) the principal is a politician, principals must be able to build cooperative relationships through persuasion and compromise approaches, the political role of the principal can develop effectively, if: the principle of mutual understanding of each other's network can be developed; the formation of alliances or coalitions, such as professional organizations, and so on; and the creation of cooperation with various parties, so that various types of activities can be carried out; (6) the principal is a diplomat. In various kinds of meetings, the principal is the official representative of the school he leads; and (7) the principal makes difficult decisions. No organization runs smoothly without problems. Likewise, the school as an organization is not free from problems and difficulties. And if there are difficulties the principal is expected to play a role as a person who can solve these difficult problems.

In carrying out their leadership, in addition to having to know and understand their duties as leaders, it is no less important than that all principals should understand and know their role. As for the roles of principals who carry out their roles as managers as revealed by Wahjosumidjo (2007) are: (1) the role of relationships between individuals; (2) the role of informational; and (3) as a decision maker. There are 4 factors in the professional competency that beginner principals must have. Factors that must be possessed by the Beginner School Head have different values according to the situation and conditions faced by the novice headmaster in delivering himself as a learning leader. From the results of this study it can be seen that the vision of learning factor has the highest percentage or average value. Thus, it can be concluded that in the professional competencies needed by the novice headmaster, novice principals need the most competence about vision of learning, then successively proceed with the factors of culture of learning, learning environment, and school-community relations.

Social competence is a person's ability to communicate, interact, cooperate, and give to others. In line with this thinking Komara (2007) defines social competence as: (1) a person's ability to interact and communicate with peers to improve professional abilities; (2) the ability to recognize and understand the functions of each social institution; and (3) the ability to collaborate both individually and in groups. Social competence is the ability to communicate and interact effectively and efficiently, both with students, teachers, parents / guardians, and the surrounding community, so that someone who has social competence will appear attractive, empathetic, collaborative, helpful, being a role model, 
communicative, and cooperative. Whereas Sumardi (2007) states that social competence is the ability to communicate, build relationships, and cooperation, accept differences, assume responsibility, respect the rights of others, and the ability to benefit others.

Hidayat (2013) states that social competence is the ability of a person as part of a society that at least includes the competence to communicate verbally, in writing, and / or cues, use information technology functionally, interact effectively with fellow professions, parents / guardians in a manner effective. In the context of schooling a principal is required to have social competence in carrying out their duties. Competencies in this field include: (1) skilled cooperation with others based on the principle of mutual benefit and benefit the school, which falls into this category is in collaboration with superiors, teachers and staff, students, other schools and other agencies; (2) able to participate in social activities in the community, the indicator is being able to play an active role in informal activities, social organizations, religion, arts, sports; and (3) having social sensitivity towards other people or groups, the indicators include acting as problem finders in school environments, being creative and being able to offer solutions, involving religious leaders, the community and government, being objective / not taking sides in resolving internal conflicts, being able to be sympathetic / be considerate of others and able to empathize with others.

The important role of social competence lies in two things, first, it lies in the personal role of the principal who lives in the community to mingle with the community. For this reason, a school principal needs to have the ability to mingle with the community, this ability includes the ability to mingle politely, be flexible with the community, be able to through activities by body, religion, and youth, arts and culture. The flexibility of associating must be possessed by the principal other than as a principal or as a teacher. Human relations skills are dexterity to place themselves in work groups. Also, communication skills that can create job satisfaction on both sides. Human relations give birth to a cooperative atmosphere and create human contact between the parties involved. Principals or school managers, besides dealing with objects, concepts and situations, are also people. Even this is the most portion.

Even for the top management (top management) who was said to have finally occupied the largest position, more than half of his activities were routine. Humans who occupy the central position are often described as the man behind the gun, humans are in control of weapons. Without having the ability in human relations, cooperation groups are not possible in harmony. These human relations skills are reflected in Danim opinion (2009), namely: (1) the skill of placing oneself in groups; (2) the skills of creating satisfaction in subordinates; (3) the open attitude towards the work group; (4) the ability to take heart through hospitality; (5) respect for ethical values; (6) equal distribution of duties and responsibilities; and (7) good faith, fairness, respect, and respect for others.

On the other hand, the reality of the role and gait of a school principal is assessed and observed both by teachers, students, peers, and their superiors as well as by the community. In fact, it is not uncommon for the goodness and weakness of the principal to be discussed by the community at large, therefore it is important for a school principal to ask for opinions from teachers, employees, students and colleagues about his daily performances both at school, in the community and immediately take advantage of opinions / criticisms to improve.

According to Mulyasa (2012) there are seven social competencies that must be possessed in order to be able to communicate and socialize effectively and efficiently namely: (1) having knowledge of customs both social and religious; (2) having knowledge of culture and tradition; (3) having knowledge of the core democracy; (4) has knowledge of aesthetics; (5) has knowledge of appreciation and social awareness; (6) has the right attitude towards knowledge and work; and (7) has loyalty to human dignity and dignity. These seven social competencies are important, so that someone can carry out two functions in school, namely: (1) the function of preservation and inheritance of social values; and (2) change agent function. Schools function to maintain the preservation of positive social values so that the inheritance of these values can run well. In addition, the school also functions as an institution that can drive changes in values and traditions towards the progress and demands of life and national development.

There are 5 factors that must be possessed by the Beginner School Principal. Factors faced by Beginner Principals have different values according to the conditions faced by beginner novice principals so that they can effectively begin their performance as learning leaders. The results showed that the social sensitivity factor had the highest percentage or average value. Thus, it can be concluded that in the social competencies needed by novice principals most need social competence factors about social sensitivity, then successively followed by factors providing assistance to other parties, communication, working together, and participating in social activities.

\section{CONCLUSION}

Personal competencies that must be possessed by beginner school principals in the category of very good or very high. Personal competence factors that must be possessed by beginner headmasters have different values according to the situation and conditions faced by beginner headmasters in developing their personality as learning leaders, beginner headmasters most need the factors of openness and responsibility, then successively followed by factors honesty, talent and interest in office, integrity, and most recently is a factor of self-confidence.

Professional competencies that must be possessed by novice school principals in order to effectively deliver themselves as learning leaders in either high or high categories. Competency factors that must be possessed by novice principals have different values according to the situations and conditions faced by novice principals in delivering themselves as learning leaders, novice principals most need competence about vision of learning, then successively proceed with factors of culture of learning, learning environment, and school-community relations.

The social competencies that beginner school principals must possess in order to effectively be able to begin their performance as learning leaders in either high 
or high categories. The factors of social competence needed by novice principals have different values according to the conditions faced by novice principals so that they can effectively begin their performance as learning leaders. The social competencies needed by beginner school principals need the most social competency factors about social sensitivity, then successively continue with the factors of providing assistance to other parties, communication, working together, and participating in social activities.

\section{REFERENCES}

[1] Bafadal, I, Wiyono, B. B., and Sobri, Y. 2015. Pengaruh Implementasi Manajemen Berbasis Sekolah terhadap Semangat Kerja Guru dan Keefektifan Sekolah. Malang: Fakultas Ilmu Pendidikan Universitas Negeri Malang.

[2] Bafadal, I. 2015. Peta Jalan Penelitian Kepemimpinan Pembelajaran yang Efeftkif: Strategi Penelitian Jangka Panjang tentang Penyiapan dan Pemberdayaan Kepala Sekolah sebagai Pemimpin Pembelajaran yang Efektif. Malang: Universitas Negeri Malang.

[3] Borg, W. R., \& Gall, M. D. 1992. Educational Research. London: Longman.

[4] Creswell, J. W., and Clark, V. P. 2007. Designing and Conducting Mixed Methods Research. London: SAGE Publication, Inc.

[5] Crow, G. M., and Matthews, L. J. 2002. Finding One's Way: How Mentoring Can Lead to Dynamic Leadership. Thousand Oaks, Calif: Corwin.

[6] Danim, S. 2009. Manajemen Kepemimpinan Transformasional Kekepalasekolahan. Jakarta: Rineka Cipta.

[7] Frymier, J. 1984. One Hundred Good Schools. Atlanta, Georgia: A Kappa Delta Pi Publication.

[8] Hidayat, S. 2013. Pengembangan Kurikulum Baru. Bandung: PT Remaja Rosdakarya.
[9] Hoy, W. K., and Miskel, C. G. 1987. Educational Administration: Theory, Research and Practice. New York: Random House.

[10] Kerlinger. F. N. 1986. Foundationsof Behavioral Research. New York: Prentice Hall.

[11] Komara, E. 2007. Peran Sertifikasi dalam Meningkatkan Profesionalisme Guru. Retrieved 2 June 2019, from www.geocities.com/endang.komara/peran.sertifikasi.dala m.meningkatkan profesionalisme.guru.html.

[12] Lunenburg. 2010. The Principal as Instructional Leader. National Forum of Educational and Supervision Journal, 27(4), 1-8

[13] Minister of National Education Regulation Number 13 of 2007 concerning Principal / Madrasah Standards. Jakarta: Citra Umbara.

[14] Muchith, S. 2007. Pembelajaran Kontekstual. Semarang: RaSAIL Media Group.

[15] Mulyasa, E. 2012. Standar Kompetensi dan Sertifikasi Guru. Bandung: Remaja Rosdakarya.

[16] Nugroho, J. S. 2008. Perilaku Konsumen: Konsep dan Impilikasi untuk Strategi dan Penelitian Pemasaran. Jakarta: Kencana.

[17] Robbins, S. P. 2003. Perilaku Organisasi. Jakarta: Index.

[18] Sarimaya, F. 2008. Sertifikasi Guru: Apa, Mengapa dan Bagaimana? Bandung: Penerbit Yrama Widya.

[19] Sergiovanni, T. J. 1987. Educational Governance and Administration. Englewood Cliffs, NJ: Prentice-Hall, Inc.

[20] Soedarsono, S. 1999. Penyemaian Jati Diri. Jakarta: PT Elex Media Komputindo.

[21] Sugiarto, E. 2002. Psikologi Pelayanan dalam Industri Jasa. Jakarta: PT Gramedia Pustaka Utama.

[22] Sumardi. 2007. Password Menuju Sukses: Rahasia Membangun Sukses Individu, Lembaga, dan Perusahaan. Jakarta: Penerbit Erlangga.

[23] Wahjosumidjo. 2007. Kepemimpinan Kepala Sekolah: Tinjauan Teoritik dan Permsasalahannya. Jakarta: PT Raja Grafindo Persada. 